\title{
Odporność połączeń klejowych na oddziaływanie wysokiej temperatury
}

\author{
Resistance of adhesive joints \\ to impact high temperature
}

\section{Streszczenie}

Wytrzymałość cieplna i odporność na podwyższone i wysokie temperatury stanowią jedne z największych niedostatków klejów i połączeń klejowych. Połączenia klejowe wykonane konstrukcyjnymi klejami organicznymi są zwykle nieodporne na oddziaływanie wysokiej temperatury. W takich warunkach pracy klej mięknie i ulega degradacji a wytrzymałość mechaniczna połączeń klejowych wyraźnie spada.

W artykule przedstawiono wpływ nagrzewania na twardość Shore'a (HSD) klejów handlowych oraz zmodyfikowanych poprzez udział napełniaczy metalowych. Przeprowadzono badania wpływu napełniaczy stanowiących proszki miedzi i aluminium na wytrzymałość mechaniczną połączeń klejowych w temperaturze 100 i $200^{\circ} \mathrm{C}$ w porównaniu z temperaturą pokojową.

Słowa kluczowe: klejenie, kleje o budowie kompozytowej, wysoka temperatura, twardość Shore'a (HSD), wytrzymałość na ścinanie połączeń klejowych

\section{Abstract}

Heat resistance, and resistance at elevated and high temperatures are one of the biggest shortcomings of glue and adhesive joints. Structural adhesive joints made with organic adhesives are generally not resistant to the effects of high temperatures. In such work conditions, the adhesive softens and is degraded and the mechanical strength of the bond drops significantly.

Article presents the influence of heating on the Shore hardness (HSD) commercial adhesives and modified by participating metal fillers. Conducted study the effect of fillers provide powders of copper and aluminum on the mechanical strength of the adhesive joints at 100 and $200^{\circ} \mathrm{C}$ in comparison to room temperature.

Keywords: bonding, adhesives of composite construction, high temperature, Shore hardness (HSD), shear strength adhesive bonds

\section{Wstęp}

Klejenie jest najstarszą technologią spajania, która dzisiaj rozwija się dynamicznie i ma największą przyszłość przed sobą. Obecnie na rynku można mieć dostęp do kilkudziesięciu różnych odmian klejów do zróżnicowanych zastosowań, pochodzących zarówno od producentów rodzimych jak i zagranicznych. Pojawiły się również i są dostępne na rynku kleje ceramiczne, których odporność na oddziaływanie temperatury sięga nawet do $1200^{\circ} \mathrm{C}$ [20]. Kleje znalazły zastosowanie w bardzo różnych dziedzinach życia i tech-

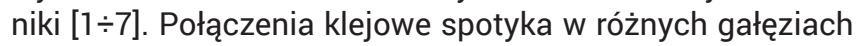
przemysłu, budownictwie, rzemiośle i w medycynie. Jednym ze szczytowych osiągnięć klejenia w kosmonautyce było zastosowanie klejów polimerowych do klejenia krzemowych płytek żaroodpornych do kadłuba promu kosmicznego "Columbia 7" [23,24]. Przewiduje się, że już niedługo połączenia klejowe będą stanowić ponad 30 \% wszystkich rodzajów połączeń stosowanych w budowie maszyn. Fakt ten wynika w znaczącej mierze z gwałtownego postępu w dziedzinie materiałów, a w szczególności kompozytów, w których to kleje na osnowie syntetycznych tworzyw znalazły szerokie zastosowanie. Wciąż rosnący udział klejenia wynika także z odmiennych właściwości połączeń w porównaniu z połączeniami wykonanymi klasycznymi metodami spajania. Do najbardziej

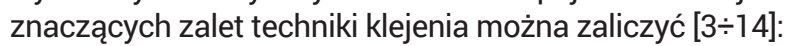

- możliwość łączenia materiałów o odmiennych właściwościach fizykochemicznych,

- równomierne rozłożenie obciążeń na całej klejonej powierzchni w porównaniu z innymi metodami spajania (rys. 1),

- możliwość łączenia elementów na dużej powierzchni i poprzez to zmniejszanie naprężeń działających na połączenie klejowe,

- zmniejszenie masy końcowego wyrobu, poprzez możliwość łączenia pocienionych elementów,

- brak strefy wpływu ciepła w połączeniach powstających w temperaturze otoczenia,

Prof. dr hab. inż. Zbigniew Mirski, dr inż. Roman Wróblewski, mgr inż. Adam Gołembiewski - Wydział Mechaniczny Politechniki Wrocławskiej. 
- zwykle brak dodatkowej obróbki po wykonaniu połączeń klejowych,

- zmniejszenie niebezpieczeństwa wystąpienia korozji elektrochemicznej.

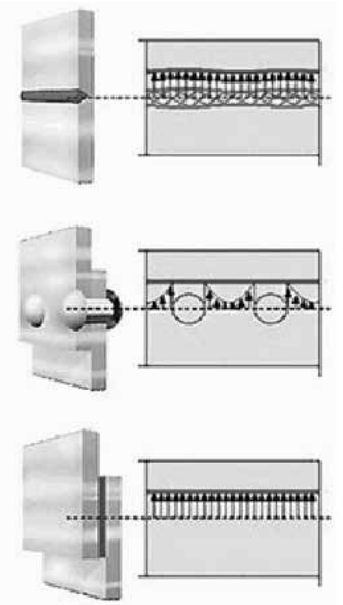

Rys. 1. Rozkład naprężeń w złączach spawanych, nitowanych i klejowych [13]

Fig. 1. Stress distribution in welding, riveted and adhesive joints [13]

\section{Właściwości klejów przeznaczonych do pracy w podwyższonej temperaturze}

Największą barierą dla zwiększonego zastosowania klejów jest wyraźne zmniejszenie parametrów wytrzymałości mechanicznej pod wpływem oddziaływania wysokiej temperatury, tj. temperatury powyżej $120^{\circ} \mathrm{C}$. Większość dostępnych klejów na rynku jest odporna na oddziaływanie temperatury do około $100^{\circ} \mathrm{C}$, tylko niewielka grupa może pracować w wyższej temperaturze. Wytrzymałość na ścinanie połączeń klejowych, podana w tablicach I-IV, odnosi się tylko do temperatury pokojowej. Dla połączeń wykonanych klejami ceramicznymi brakuje też danych dotyczących wytrzymałości mechanicznej w wysokiej temperaturze (tabl. VI).

Ze względu na budowę chemiczną i sposób utwardzania klejów odpornych na oddziaływanie wysokiej temperatury wyróżnić można kleje [1]:

- na osnowie żywicy metakrylowej (tabl. I),

- na osnowie żywicy epoksydowej (tabl. I),

- silikonowe (tabl. II),

- anaerobowe (tabl. III),

- utwardzane światłem UV (tabl. IV),

- termotopliwe (tabl. V),

- ceramiczne (tabl. VI).

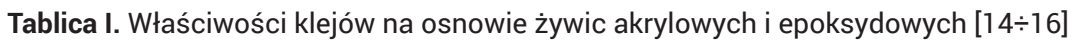

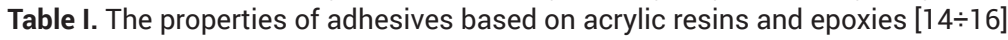

\begin{tabular}{|c|c|c|c|c|c|c|}
\hline Lp. & Oznaczenie & Baza chemiczna & $\begin{array}{l}\text { Wytrzymałość } \\
\text { na ścinanie } \\
\text { [MPa] }\end{array}$ & $\begin{array}{c}\text { Zakres } \\
\text { temperatury pracy } \\
{\left[{ }^{\circ} \mathrm{C}\right]}\end{array}$ & Zastosowanie & Uwagi \\
\hline 1 & $\begin{array}{c}\text { Loctite F246 } \\
{[14]}\end{array}$ & $\begin{array}{l}\text { żywica } \\
\text { akrylowa }\end{array}$ & 35 & do 120 & $\begin{array}{c}\text { produkt ogólnego } \\
\text { zastosowania }\end{array}$ & $\begin{array}{c}\text { klej } \\
\text { jednoskładnikowy }\end{array}$ \\
\hline 2 & $\begin{array}{c}\text { Maxweld M2 } \\
\text { MC-2661 } \\
{[15]}\end{array}$ & $\begin{array}{c}\text { żywica } \\
\text { metakrylowa }\end{array}$ & $<30$ & $\begin{array}{c}-55-+180 \\
\left(45 \operatorname{min~w~} 220^{\circ} \mathrm{C}\right)\end{array}$ & $\begin{array}{c}\text { do metali, } \\
\text { niektórych tworzyw } \\
\text { sztucznych }\end{array}$ & $\begin{array}{l}\text { łączy ze sobą poli- } \\
\text { węglany i metale, } \\
\text { wiele wersji } \\
\text { kolorystycznych }\end{array}$ \\
\hline 3 & $\begin{array}{c}\text { Loctite Hysol } 9514 \\
{[14]}\end{array}$ & epoksyd & $\begin{array}{c}46 \text { - stal śrutowana, } \\
32 \text { - stal nierdzew- } \\
\text { na, } 20 \text { - stal } \\
\text { ocynkowana }\end{array}$ & $-55-+200$ & $\begin{array}{l}\text { metale, ceramika, } \\
\text { większość tworzyw } \\
\text { sztucznych }\end{array}$ & $\begin{array}{c}\text { klej jednoskładni- } \\
\text { kowy, utwardzanie } \\
\text { ciepłem, wysoka } \\
\text { odporność na } \\
\text { działanie } \\
\text { czynników mecha- } \\
\text { nicznych }\end{array}$ \\
\hline 4 & $\begin{array}{c}\text { Araldite } 2011 \\
\text { [16] }\end{array}$ & epoksyd & $\begin{array}{c}\text { 26-aluminium, } \\
25 \text { - stal, } 23 \text { - stal } \\
\text { nierdzewna, } \\
\text { 22- miedź, 5- ABS, } \\
\text { 3- PVC }\end{array}$ & $-60-+100$ & $\begin{array}{c}\text { metal, kamień, } \\
\text { ceramika, } \\
\text { tworzywo sztuczne }\end{array}$ & $\begin{array}{c}\text { sprawdzona odpor- } \\
\text { ność starzeniowa } \\
\text { w rzeczywistych } \\
\text { warunkach pracy } \\
\text { przez } 5 \text { lat }\end{array}$ \\
\hline
\end{tabular}

Tablica II. Właściwości klejów na osnowie silikonów [14,17]

Table II. The properties of adhesives based on silicones $[14,17]$

\begin{tabular}{|c|c|c|c|c|c|c|}
\hline Lp. & Oznaczenie & Baza chemiczna & $\begin{array}{c}\text { Wytrzymałość } \\
\text { na rozciąganie } \\
\left(23+/{ }^{\circ} \mathrm{C}\right) \\
{[\mathrm{MPa}]}\end{array}$ & $\begin{array}{c}\text { Zakres } \\
\text { temperatury pracy } \\
{\left[{ }^{\circ} \mathrm{C}\right]}\end{array}$ & Zastosowanie & Uwagi \\
\hline 1 & $\begin{array}{c}\text { Loctite 5399 } \\
{[14]}\end{array}$ & silikon acetoksy & 3,3 & +300 & $\begin{array}{c}\text { do klejenia } \\
\text { i uszczelniania } \\
\text { szkła, metali } \\
\text { i ceramiki }\end{array}$ & $\begin{array}{c}\text { klej jednoskładni- } \\
\text { kowy, wydłużenie } \\
\text { przy rozciąganiu } \\
500 \%\end{array}$ \\
\hline 2 & $\begin{array}{c}\text { Kisling AG } \\
\text { Ergo 3020 } \\
{[17]}\end{array}$ & $\begin{array}{c}\text { silikon oksymowy } \\
\text { modyfikowany }\end{array}$ & 2 & $\begin{array}{c}\text { nasadki } \\
\text { i kołnierze } \\
\text { w silnikach spali- } \\
\text { nowych, kołnierze } \\
\text { wentylatorów, } \\
\text { pokrywy skrzyni } \\
\text { biegów, miski } \\
\text { olejowe }\end{array}$ & $\begin{array}{c}\text { klej przeznaczony } \\
\text { głównie do prze- } \\
\text { mysłu motoryza- } \\
\text { cyjnego }\end{array}$ \\
\hline
\end{tabular}


Dodatkową grupą klejów, które mogą pracować w wysokiej temperaturze stanowią kleje o budowie kompozytowej, jednak- że ich właściwości w dużej mierze zależą zarówno od osnowy jak i rodzaju i właściwości fazy wzmacniającej (zbrojenia) [8].

Tablica III. Właściwości klejów anaerobowych [14,18]

Table III. Properties of anaerobic adhesives $[14,18]$

\begin{tabular}{|c|c|c|c|c|c|c|}
\hline Lp. & Oznaczenie & Baza chemiczna & $\begin{array}{c}\text { Wytrzymałość } \\
\text { na ścinanie przy } \\
\text { rozciąganiu [MPa] }\end{array}$ & $\begin{array}{c}\text { Zakres } \\
\text { temperatury pracy } \\
{\left[{ }^{\circ} \mathrm{C}\right]}\end{array}$ & Zastosowanie & Uwagi \\
\hline 1 & $\begin{array}{c}\text { Loctite 620 } \\
{[14]}\end{array}$ & metakrylan & $>24,1$ & $-55-+230$ & $\begin{array}{c}\text { do klejenia } \\
\text { i uszczelniania } \\
\text { szkła, metali } \\
\text { i ceramiki }\end{array}$ & $\begin{array}{c}\text { klej jednoskładni- } \\
\text { kowy, wydłużenie } \\
\text { przy rozciąganiu } \\
500 \%\end{array}$ \\
\hline 2 & $\begin{array}{c}\text { Loxeal 24:18 } \\
{[18]}\end{array}$ & metakrylan & $2 \div 4$ & $-55-+150$ & $\begin{array}{c}\text { zabezpieczanie } \\
\text { gwintów przed } \\
\text { luzowaniem się } \\
\text { i odkręcaniem, } \\
\text { przeciekami } \\
\text { i korozją }\end{array}$ & $\begin{array}{c}\text { średnica gwintu } \\
\text { M24 }\end{array}$ \\
\hline
\end{tabular}

Tablica IV. Właściwości klejów utwardzanych światłem UV [14,19]

Table IV. Properties of UV light curable adhesives [14,19]

\begin{tabular}{|c|c|c|c|c|c|c|}
\hline Lp. & Oznaczenie & Baza chemiczna & $\begin{array}{c}\text { Wytrzymałość } \\
\text { na ścinanie [MPa] }\end{array}$ & $\begin{array}{c}\text { Zakres } \\
\text { temperatury pracy } \\
{\left[{ }^{\circ} \mathrm{C}\right]}\end{array}$ & Zastosowanie & Uwagi \\
\hline 1 & $\begin{array}{c}\text { Loctite 3926 } \\
{[14]}\end{array}$ & klej akrylowy & 7 & $-40-+150$ & $\begin{array}{c}\text { do klejenia } \\
\text { i uszczelniania } \\
\text { szkła, metali } \\
\text { i ceramiki }\end{array}$ & $\begin{array}{c}\text { klej jednoskładni- } \\
\text { kowy, wydłużenie } \\
\text { przy rozciąganiu } \\
500 \%\end{array}$ \\
\hline 2 & $\begin{array}{c}\text { Loxeal 83:61 } \\
{[18]}\end{array}$ & ester metakrylowy & - & $-55-+175$ & $\begin{array}{c}\text { przeznaczony do } \\
\text { klejenia szkła z in- } \\
\text { nymi materiałami }\end{array}$ & $\begin{array}{c}\text { maksymalna } \\
\text { szczelina } 0,01-0,12 \\
\text { mmała lepkość } \\
400-600 \text { mPa.s }\end{array}$ \\
\hline
\end{tabular}

Tablica V. Właściwości klejów termotopliwych [14]

Table V. Properties of hot melt adhesives [14]

\begin{tabular}{|c|c|c|c|c|c|c|}
\hline Lp. & Oznaczenie & Baza chemiczna & $\begin{array}{c}\text { Temperatura } \\
\text { mięknienia } \\
{\left[{ }^{\circ} \mathrm{C}\right]}\end{array}$ & $\begin{array}{c}\text { Zakres } \\
\text { temperatury pracy } \\
{\left[{ }^{\circ} \mathrm{C}\right]}\end{array}$ & Zastosowanie & Uwagi \\
\hline 1 & $\begin{array}{c}\text { Macromelt } 6238 \\
{[14]}\end{array}$ & poliamid & $+133-+145$ & $+180-+220$ & $\begin{array}{c}\text { dobra adhezja do } \\
\text { metali } i \text { tworzyw } \\
\text { sztucznych }\end{array}$ & $\begin{array}{c}\text { odporny na olej, } \\
\text { nie zawiera } \\
\text { rozpuszczalnika }\end{array}$ \\
\hline 2 & $\begin{array}{c}\text { Technomelt } \\
\text { PS-M8783 } \\
{[14]}\end{array}$ & $\begin{array}{c}\text { kauczuk } \\
\text { termo-plastyczny }\end{array}$ & $+132-+142$ & $+160-+180$ & $\begin{array}{c}\text { dobra adhezja } \\
\text { do metali i two- } \\
\text { rzyw sztucznych }\end{array}$ & $\begin{array}{c}\text { kontaktowy } \\
(\text { "wiecznie żywy") }\end{array}$ \\
\hline
\end{tabular}

Tablica VI. Właściwości klejów ceramicznych [20,21]

Table VI. Ceramic adhesive properties [20,21]

\begin{tabular}{|c|c|c|c|c|c|c|}
\hline Lp. & Oznaczenie & Baza chemiczna & $\begin{array}{l}\text { Wytrzymałość } \\
\text { na ścinanie } \\
\text { [MPa] }\end{array}$ & $\begin{array}{c}\text { Zakres } \\
\text { temperatury } \\
\text { pracy }\left[{ }^{\circ} \mathrm{C}\right]\end{array}$ & Zastosowanie & Uwagi \\
\hline 1 & $\begin{array}{c}\text { Technicoll } \\
\text { Silicate } 1200 \\
{[20]}\end{array}$ & krzemiany & - & $-40-+1200$ & $\begin{array}{l}\text { montaż, naprawa } \\
\text { oraz uszczelnianie } \\
\text { układów wydecho- } \\
\text { wych, wykładzin } \\
\text { szamotowych } \\
\text { oraz metalowych } \\
\text { odprowadzających } \\
\text { spaliny i ciecze }\end{array}$ & - \\
\hline 2 & $\begin{array}{c}\text { Resbond } 919 \\
\text { [21] }\end{array}$ & tlenek magnezu & - & +1500 & - & $\begin{array}{c}\text { podwyższone para- } \\
\text { metry dielektrycz- } \\
\text { ne, stałe w czasie } \\
\text { zarówno na zimno, } \\
\text { jak i w podwyższo- } \\
\text { nej temperaturze, } \\
\text { dobre parametry } \\
\text { wytrzymałościowe }\end{array}$ \\
\hline
\end{tabular}




\section{Kleje stosowane w badaniach}

Do badań własnych wybrano dwa rodzaje klejów. Pierwszym był klej ceramiczny Silicate 1200 z napełniaczem stanowiącym krzemiany [20] drugim natomiast Agomet F330 na bazie żywicy metakrylowej [22]. Dodatkowo do kleju Agomet F330 dodano napełniacze, w postaci proszku miedzianego oraz proszku glinu.

Klej Silicate 1200 jest ogniotrwałym klejem ceramicznym, nadającym się do klejenia materiałów pracujących w temperaturze powyżej $1000^{\circ} \mathrm{C}$. Jest on odporny na oddziaływanie spalin, rozcieńczonych kwasów, wody, chemikaliów oraz ujemnej temperatury [20]. Właściwości kleju Silicate 1200 zamieszczono w tablicy VII.

Tablica VII. Właściwości kleju Silicate 1200 [20] Table VII. Adhesive properties Silicate 1200 [20]

\begin{tabular}{|c|c|}
\hline Gęstość, g/ml & 1,01 \\
Konsystencja & pasta \\
Czas utwardzania, $\mathrm{h}$ & 24 \\
Odporność na temperaturę, $^{\circ} \mathrm{C}$ & $-40-+1200$ \\
\hline
\end{tabular}

Klej Agomet F330 jest klejem dwuskładnikowym, do żywicy metakrylowej dodawano utwardzacz w postaci proszku. Agomet F330 charakteryzuje się dużą szybkością utwardzania - około kilku do kilkunastu min (prędkość utwardzania zależy od ilości dodanego utwardzacza, zwykle dodaje się $3 \div 5 \%$ wag.), dobrą wytrzymałością na ścinanie oraz oddzieranie. Nadaje się do spajania stali, metali nieżelaznych oraz tworzyw sztucznych, takich jak: twardy PVC, ABS, polistyren, poliwęglan, szkoło akrylowe, poliestry utwardzalne. Inne właściwości kleju Agomet F330 zamieszczono w tablicy VIII.

Tablica VIII. Właściwości kleju Agomet F330 [22]

Table VIII. Adhesive properties Agomet F330 [22]

\begin{tabular}{|c|c|}
\hline Gęstość, g/ml & 1,01 \\
Konsystencja & gęsty płyn \\
Czas uzyskania końcowej & 24 \\
wytrzymałości, $\mathrm{h}$ & od -40 do 130 (krótkotrwale 200) \\
Odporność na temperaturę, ${ }^{\circ} \mathrm{C}$ & $33-\mathrm{Al}$, stal \\
Wytrzymałość na ścinanie & $29-\mathrm{Cu}$, mosiądz \\
połączeń klejowych, MPa & \\
\hline
\end{tabular}

Wygrzewanie połączenia $\mathrm{w}$ temperaturze $200{ }^{\circ} \mathrm{C}$ przez 4 godziny, a następne ochłodzenie do temperatury pokojowej nie zmniejsza wytrzymałości połączenia klejowego. W tablicy IX przedstawiono wpływ długotrwałego 7 dniowego wygrzewania a następnie ochłodzenia próbki do temperatury pokojowej na wytrzymałość stalowego połączenia klejowego.

Tablica IX. Wpływ wygrzewania na wytrzymałość na ścinanie połączeń wykonanych klejem Agomet F330 w MPa [22]

Table IX. Effect of soaking on the shear strength of the adhesive joints made with Agomet F330 in MPa [22]

\begin{tabular}{|c|c|c|c|}
\hline \multirow{2}{*}{$\begin{array}{c}\text { Sposób } \\
\text { przygotowania } \\
\text { powierzchni }\end{array}$} & \multicolumn{3}{|c|}{ Temperatura wygrzewania, ${ }^{\circ} \mathrm{C}$} \\
\cline { 2 - 4 } & 20 & 120 & 175 \\
\hline Odtłuszczenie & 31 & 31,6 & 31,7 \\
\hline $\begin{array}{c}\text { Schropowacenie } \\
\text { i odtłuszczenie }\end{array}$ & 35,8 & 35,8 & 35,3 \\
\hline
\end{tabular}

\section{Badania własne}

Kleje o budowie kompozytowej, przygotowano na bazie kleju Agomet F330, dodając po 60\% wag. napełniaczy. Stanowiły je: nieregularny proszek glinu o granulacji od 0 do $100 \mu \mathrm{m}$ (rys. 2 a) oraz kulisty proszek miedziany o granulacji od 0 do $106 \mu \mathrm{m}$ (rys. 2 b). Zastosowane napełniacze wykazują dużą przewodność cieplną, zaliczaną do największych wśród metali, których ceny są stosunkowo niskie. Przewodność cieplna miedzi wynosi około 390-400 W/(m·K), natomiast glinu $237 \mathrm{~W} /(\mathrm{m} \cdot \mathrm{K})$.

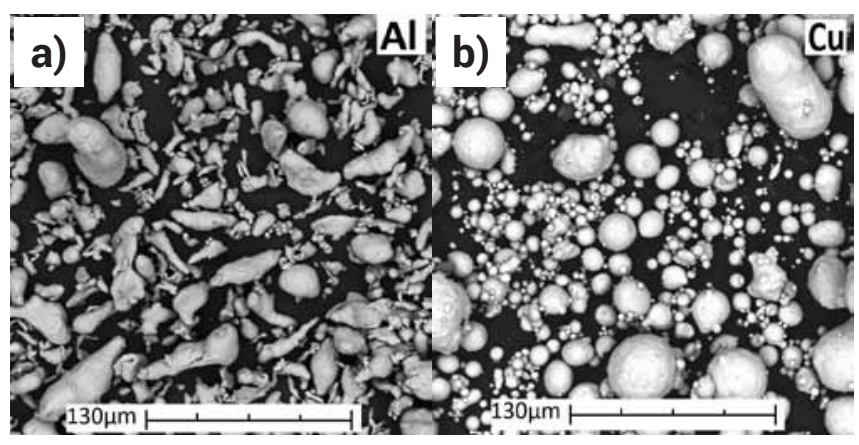

Rys. 2. Proszek aluminium (a), proszek miedzi (b) [1]

Fig. 2. Aluminium powder (a), copper powder (b) [1]

\section{Próby wytrzymania klejów w wysokiej temperaturze}

W próbie tej sprawdzono oddziaływanie wysokiej temperatury na poszczególne kleje oraz określono wpływ wygrzewania na ich twardość zmierzoną durometrem Shore'a typu D ('Sh D). Na odtłuszczone alkoholem izopropylowym blaszki ze stali S235JR naniesiono badane próbki klejów, na jednej próbce umieszczono po cztery porcje klejów o grubości warstwy ok. 3,0 mm. Wymiary podłoża stalowego wynosiły $26,5 \times 122,5 \times 2 \mathrm{~mm}$ (rys. 3) [1].

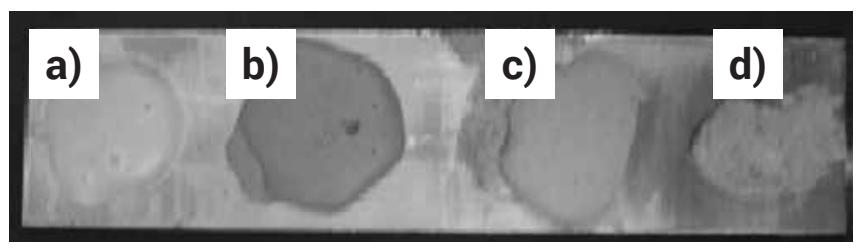

Rys. 3. Próbki klejów do wygrzewania w wysokiej temperaturze oraz pomiarów twardości: Agomet F330 (a), Agomet F330 + Cu (b), Agomet F330 + Al (c), Silicate 1200 (d) [1]

Fig. 3. Samples for soaking at high temperature and hardness research: Agomet F330 (a), Agomet F330 + Cu (b), Agomet F330 + Al (c), Silicate 1200 (d) [1]

Próby te polegały na wygrzewaniu klejów w suszarce laboratoryjnej Wamed typu SUP-65M w stałej temperaturze 200 oraz $250^{\circ} \mathrm{C}$. Czasy wygrzewania wynosiły: 5, 10, 15, 22 oraz 40 min. Po wygrzewaniu próbki poddano ocenie wizualnej oraz pomiarom twardości durometrem Shore'a - skala D.

Ocena wizualna polegała na określeniu zmiany barwy na powierzchni i pod powierzchnią kleju, co pozwoliło stwierdzić czy klej dobrze zniósł próbę cieplną czy już rozpoczęły się w nim procesy destrukcji.

\section{Wygrzewanie w temperaturze $200^{\circ} \mathrm{C}$}

Ceramiczny klej Silicate 1200 nie zmienił zasadniczo swojej barwy. Warstwa kleju Silicate 1200 odpadła jednak od każdej próbki. Może to wynikać z niedostatecznych właściwości adhezyjnych samego kleju. Klej Agomet F330 już po 5 min przebywania w temperaturze $200{ }^{\circ} \mathrm{C}$ lekko zmienił barwę, po 40 min przebywania w suszarce przybrał kolor ciemno brązowy, co może wnioskować o znaczącej powierzchniowej zmianie struktury. Klej Agomet F330, do którego dodano proszek aluminiowy zaczął zmieniać 
swoją barwę dopiero po $40 \mathrm{~min}$ przebywania w temperaturze $200{ }^{\circ} \mathrm{C}$. Barwa kleju z miedzianym napełniaczem już po 10 min przebywania w temperaturze $200{ }^{\circ} \mathrm{C}$ uległa zmianie, natomiast po 40 min klej był już koloru ciemnoczekoladowego brązu. Po usunięciu cienkiej utlenionej warstwy klejów ich barwa pod powierzchnią nie uległa większym zmianom w porównaniu ze stanem wyjściowym [1].

\section{Wygrzewanie w temperaturze $250{ }^{\circ} \mathrm{C}$}

Klejem, który najszybciej zmienił barwę na kolor ciemno brunatny był klej z dodatkiem proszku miedzianego, co może świadczyć o jego utlenieniu powierzchniowym. Klej Silicate 1200 podobnie jak w poprzedniej próbie odpadł od każdej próbki. Można wnioskować, że klej mimo dobrej odporności na temperaturę sięgającą nawet do $1200{ }^{\circ} \mathrm{C}$, nie nadaje się do ogólnego klejenia połączeń pracujących pod obciążeniem mechanicznym wymaga też wyraźnego zwiększenia sił adhezji do łączonych powierzchni [1]. Jego zastosowanie dotyczy przede wszystkim połączeń o charakterze uszczelniającym, ze szczeliną i gniazdem półotwartym.

\section{Pomiar twardości durometrem Shore'a - skala D w temperaturze pokojowej}

Pomiary twardości klejów przeprowadzono durometrem Shore'a - skala D, firmy Sauter, z penetratorem w kształcie ostrej iglicy (rys. 4). Wartości twardości, stanowiących średnie z 5 pomiarów, zamieszczono $w$ tablicy $X$.

$\mathrm{Na}$ podstawie wyników pomiarów twardości można stwierdzić, że wygrzewanie $w$ temperaturze $250{ }^{\circ} \mathrm{C}$ niezależnie od czasu wygrzewania nie wpływa znacząco na twardość kleju. W warstwie kleju Silicate 1200 pojawiły się pęknięcia i rozwarstwienia, co istotnie wpłynęło na wartości pomiarów próbek wygrzewanych zwłaszcza w ciągu 15 oraz $40 \min [1]$.

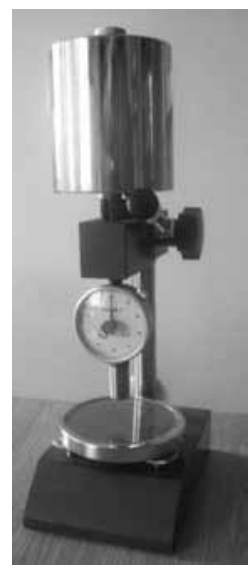

Rys. 4. Durometr Shore'a typu D umieszczony na statywie [1]

Fig. 4. Shore durometer type $D$ mounted on a tripod [1]

Tablica X. Zestawienie twardości klejów Shore'a - D ( $\left.{ }^{\circ} \mathrm{Sh}\right)$, przed i po wygrzewaniu w temperaturze $250^{\circ} \mathrm{C}[1]$

Table X. Selection of the hardness Shore - D ( $\left.{ }^{\circ} \mathrm{Sh}\right)$ of the adhesive before and after annealing at $250^{\circ} \mathrm{C}[1]$

\begin{tabular}{|c|c|c|c|c|c|c|}
\hline \multirow{2}{*}{ Klej } & \multicolumn{6}{|c|}{ Czas wygrzewania [min] } \\
\cline { 2 - 7 } & 0 & 5 & 10 & 15 & 22 & 40 \\
\hline Agomet F330 & 85 & 83 & 82 & 85 & 82 & 87 \\
\hline Agomet F330 + Cu & 87 & 81 & 86 & 86 & 84 & 86 \\
\hline Agomet F330 + Al & 92 & 90 & 85 & 86 & 82 & 89 \\
\hline Silicate 1200 & 88 & 92 & 86 & 77 & 90 & 75 \\
\hline
\end{tabular}

\section{Statyczna próba ścinania połączeń klejowych}

Statyczną próbę ścinania połączeń klejowych przeprowadzono zarówno $\mathrm{w}$ temperaturze pokojowej $\left(23^{\circ} \mathrm{C}\right)$, jak i w temperaturze 100 i $200{ }^{\circ} \mathrm{C}$. Powierzchnie próbek ze stali C45 obrobiono poprzez frezowanie i następnie odtłuszczono. Połączenie klejowe miało powierzchnię 217,5 mm² (15x14,5 mm). Szczelina klejowa wynosiła 0,2 mm, ustalono ją za pomocą dwóch drucików stalowych o średnicy 0,2 mm. Przykładowe połączenie klejowe pokazano na rysunku 5 [1].

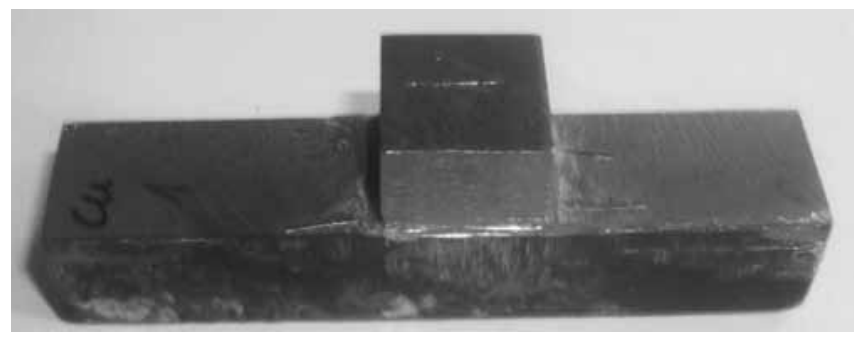

Rys. 5. Połączenie klejowe ze stali C45 przeznaczone do statycznej próby ścinania [1]

Fig. 5. Adhesive joint of steel C45 for static test of shear [1]

Próbki klejowe ścinano w przyrządzie na maszynie wytrzymałościowej o zakresie obciążeń do $1 \mathrm{~T}$, z komorą nagrzewaną do temperatury $300{ }^{\circ} \mathrm{C}$ (rys. 6). Stosowano prędkość przesuwu belki poprzecznej maszyny równą $0,1 \mathrm{~cm} / \mathrm{min}$. Do badań pobierano po 5 próbek z każdej grupy połączeń klejowych.

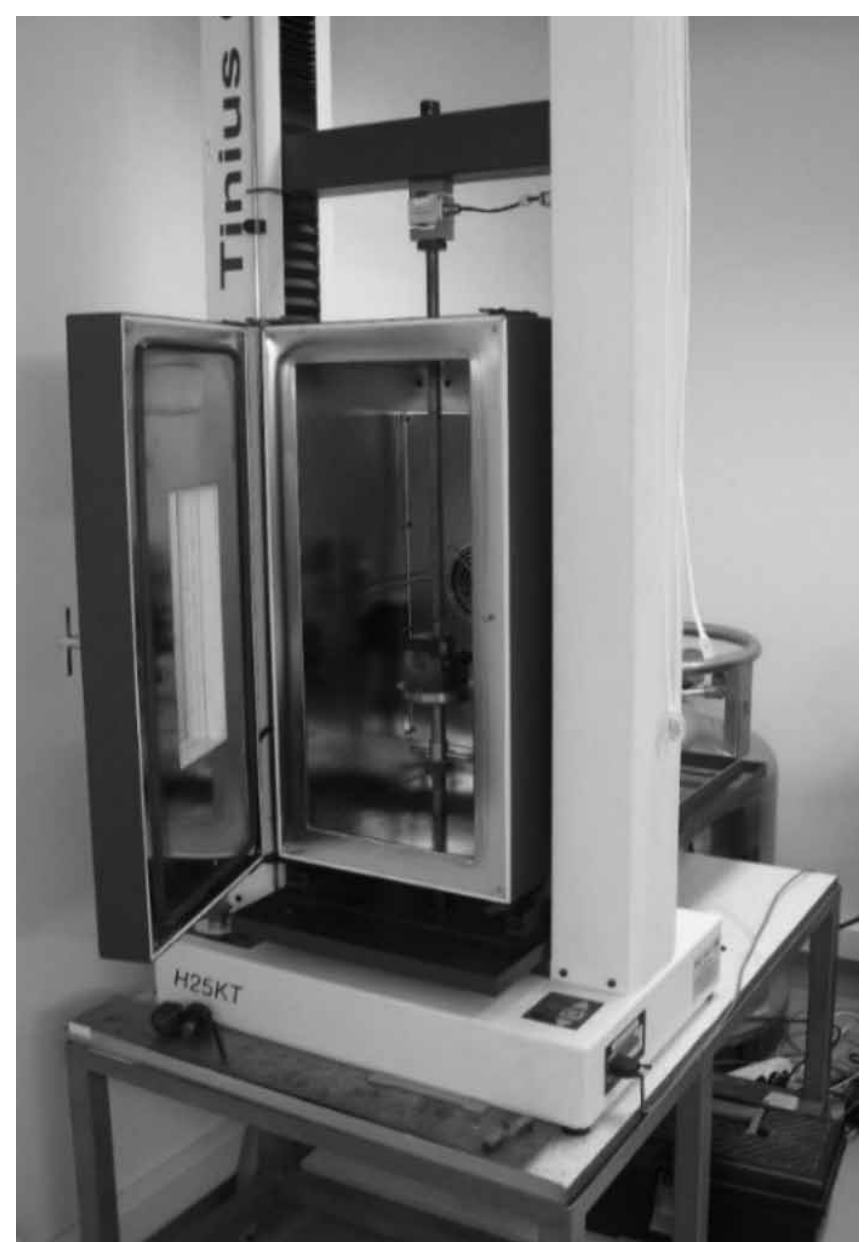

Rys. 6. Maszyna wytrzymałościowa H25KT firmy Tinius Olsen z komorą grzewczą do temperatury $300^{\circ} \mathrm{C}$ [1]

Fig. 6. The testing machine Tinius Olsen , $\mathrm{H} 25 \mathrm{KT}$ with heating chamber to a temperature $300^{\circ} \mathrm{C}[1]$ 
Wyniki statycznej próby ścinania połączeń klejowych zamieszczono w tablicy XI i przedstawiono na rysunku 7. Największe różnice w wytrzymałości na ścinanie połączeń klejowych są zauważalne w temperaturze pokojowej $\left(23^{\circ} \mathrm{C}\right)$. Wpływ napełniaczy jest tu najbardziej znaczący. W przypadku dodatku proszku glinu wzrost wytrzymałości na ścinanie wyniósł $10 \mathrm{MPa}(41 \%)$, natomiast dla dodatku sferycznego proszku miedzianego - 11,6 MPa (47\%) w porównaniu z klejem Agomet F330 bez napełniaczy. Przełomy po próbie ścinania miały najczęściej charakter adhezyjno-kohezyjny. Rozrzut wartości w poszczególnych próbkach jest stosunkowo duży. Odchylenie standardowe jest najmniejsze w przypadku wytrzymałości na ścinanie próbek klejonych przy użyciu czystego kleju Agomet F330 [1].

W temperaturze $100{ }^{\circ} \mathrm{C}$ dodane proszki aluminium oraz miedzi do kleju Agomet F330 podniosły również wytrzymałość mechaniczną połączeń klejowych. W przypadku kleju z dodatkiem proszku aluminiowego wzrost ten wyniósł prawie $20 \%$ w porównaniu z klejem bez napełniacza. Natomiast w przypadku dodatku proszku miedzi wzrost ten był jeszcze większy i wyniósł $28 \%$. We wszystkich przeprowadzonych próbach w temperaturze $100{ }^{\circ} \mathrm{C}$ przełomy połączeń klejowych miały zróżnicowany charakter w zależności od rodzaju kleju. W przypadku kleju kompozytowego z napełniaczem Cu dominujący był przełom adhezyjny, dla kleju z proszkiem aluminiowym występował przełom o charakterze kohezyjnym a dla kleju Agomet F330 przełom miał charakter mieszany adhezyjno - kohezyjny.

Właściwości wytrzymałościowe połączeń klejowych w temperaturze $200^{\circ} \mathrm{C}$ są już niewielkie, wynoszą poniżej $1 \mathrm{MPa}$. Charakter przełomu połączeń klejowych był najczęściej adhezyjno - kohezyjny. Klej Agomet F330 jest oparty na żywicy metakrylowej stanowiącej związek organiczny, który w temperaturze $200^{\circ} \mathrm{C}$ ulega zmiękczeniu, mimo ograniczenia jego udziału przez dodatek napełniaczy metalowych [1]. Wpływ napełniaczy na wytrzymałość na ścinanie połączeń klejowych jest już w tej temperaturze niezauważalny [1].

Przy niewielkich obciążeniach mechanicznych i przy zachowaniu ewentualnie wymaganej szczelności połączenia, nawet tak niewielka wytrzymałość na ścinanie, poniżej 1 MPa może okazać się wystarczająca. Świadczą o tym dane z karty technicznej środka uszczelniającego Terostat - 930 z rodziny MS-polimerów, o właściwościach klejących, którego wytrzymałość na ścinanie wynosi 0,85 MPa [25].

Tablica XI. Zestawienie średnich wartości wytrzymałości na ścinanie połączeń klejowych w temperaturze pokojowej, 100 i $200{ }^{\circ} \mathrm{C}$ (w nawiasach podano odchylenie standardowe) [1]

Table XI. A comparison of average values from shear strength of samples carried out at room temperature, 100 and $200{ }^{\circ} \mathrm{C}$ (in parentheses are the standard deviation of the sample) [1]

\begin{tabular}{|c|c|c|c|c|}
\hline \multirow{2}{*}{ Lp. } & \multirow{2}{*}{ Klej } & \multicolumn{3}{|c|}{ Wytrzymałość na ścinanie, MPa } \\
\cline { 3 - 5 } & $23{ }^{\circ} \mathrm{C}$ & $100{ }^{\circ} \mathrm{C}$ & $200{ }^{\circ} \mathrm{C}$ \\
\hline 1 & $\begin{array}{c}\text { Agomet } \\
\text { F330 }\end{array}$ & $24,5(5,8)$ & $7,2(1,8)$ & $0,5(0,1)$ \\
\hline 2 & $\begin{array}{c}\text { Agomet } \\
\text { F330 + Cu }\end{array}$ & $36,1(10,2)$ & $9,2(1,7)$ & $0,3(0,1)$ \\
\hline 3 & $\begin{array}{c}\text { Agomet } \\
\text { F330 + Al }\end{array}$ & $34,5(8,5)$ & $8,6(1,4)$ & $0,6(0,1)$ \\
\hline
\end{tabular}

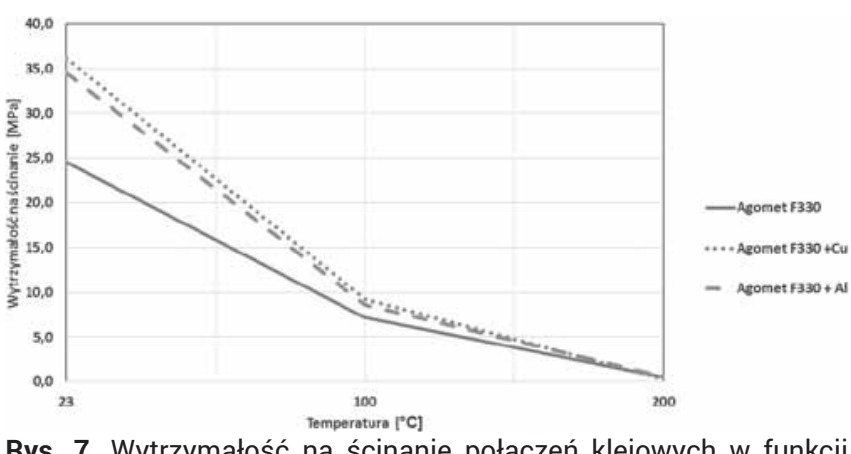

Rys. 7. Wytrzymałość na ścinanie połączeń klejowych w funkcji temperatury [1]

Fig. 7. Shear strength of the bond as a function of temperature [1]

\section{Wnioski}

Przeprowadzone badania pozwalają na sformułowanie następujących wniosków:

Klej ceramiczny Silicate 1200 był trudny do dozowania z uwagi na swoją konsystencję. Jego właściwości adhezyjne w podwyższonej temperaturze pracy są niezadowalające. Nadaje się do klejenia materiałów z półzamkniętym gniazdem (szczeliną) przy niewielkich obciążeniach mechanicznych. Połączenia wykonane klejem ceramicznym okazały się kruche. Klej nie ulega zmiękczeniu oraz zauważalnemu powierzchniowemu utlenieniu pod wpływem długotrwałego (40 min) wygrzewania w temperaturze $250^{\circ} \mathrm{C}$.

Wygrzewanie badanych klejów w temperaturze sięgającej do $250{ }^{\circ} \mathrm{C}$ nie wpływa znacząco na wartość twardości Shore'a typu D, mierzoną w temperaturze pokojowej.

Wpływ napełniaczy dodanych do osnowy kleju Agomet F330, stanowiącej żywicę metakrylową, jest istotny w temperaturze pokojowej i w temperaturze $100^{\circ} \mathrm{C}$. Sferyczny proszek miedzi podniósł wytrzymałość na ścinanie połączenia klejowego w temperaturze 23 i $100{ }^{\circ} \mathrm{C}$ odpowiednio o 47 i $28 \%$ w porównaniu z połączeniami bez napełniacza. Proszek aluminium wykazał mniejszy wpływ na wzrost wytrzymałości na ścinanie połączenia klejowego. Wzrost ten wyniósł $40 \%$ w przypadku temperatury pokojowej i $21 \%$ w temperaturze $100{ }^{\circ} \mathrm{C}$.

Połączenia wykonane klejem syntetycznym Agomet F330 na bazie organicznej tracą swoje właściwości wytrzymałościowe w temperaturze $200^{\circ} \mathrm{C}$ w wyniku zmiękczenia ich osnowy. Napełniacze metalowe nie mają wtedy wpływu na wytrzymałość mechaniczną kompozytu klejowego. Wytrzymałość na ścinanie połączeń klejowych o budowie kompozytowej w temperaturze $200^{\circ} \mathrm{C}$ jest niewielka i wynosi w granicach 0,3-0,6 MPa. To jednak może być wystarczające w warunkach małej obciążalności mechanicznej.

\section{Literatura}

[1] GOŁEMBIEWSKI A. Badania połączeń wykonanych klejami konstrukcyjnymi w podwyższonej temperaturze, Praca magisterska pod kier. prof. Z. Mirskiego, Wydział Mechaniczny Politechniki Wrocławskiej, Wrocław 2015.
[2] PIWOWARCZYK T.: Zwiększanie oddziaływań adhezyjnych i kohezyjnych w połączeniach klejowych węglików spiekanych ze stalą C45, Rozprawa doktorska, Politechnika Wrocławska, Wrocław 2008. 
[3] PILARCZYK J. (red.): Poradnik inżyniera - Spawalnictwo, tom 2, WNT Warszawa 2014

[4] CHESTER R.J., WALKER K.F., CHALKLEY P.D.: Adhesively bonded repairs to primary aircraft structure, International Journal of Adhesion and Adhesives, nr 19/1999.

[5] GODZIMIRSKI J.: Analiza wytrzymałości połączeń klejowych elementów metalowych obciążonych statycznie, Rozprawa habilitacyjna, Wojskowa Akademia Techniczna, Warszawa 1988.

[6] GODZIMIRSKI J.: Wytrzymałość doraźna konstrukcyjnych połączeń klejowych, WNT, Warszawa 2002

[7] PETRIE E., M.: Handbook of adhesives and sealants, McGraw-Hill, New York, 2000

[8] Mirski Z., Granat K., Piwowarczyk T.: Zastosowanie ciepłoprzewodzacych mas klejowych w odlewnictwie, Archives of Foundry Engineering, vol. 8, nr 1/2008, s. 215-218.

[9] Mirski Z., Piwowarczyk T., Zych B.: Przewodność cieplna połączeń klejowych o budowie kompozytowej, Energetyka, zeszyt tematyczny nr 14/2007, s. $72-75$

[10] Mirski Z., Piwowarczyk T.: Composite adhesive joints of hardmetals with steel, Adhesives of Civil and Mechanical Engineering, vol. IX. No. 2/2009, s. 93-104.

[11] MIRSKI Z., PIWOWARCZYK T.: Klejenie węglików spiekanych i stali w aspekcie zastosowań w przemyśle narzędziowym. VIII Konferencja Naukowo - Techniczna, Problemy i innowacje w remontach energetycznych PIRE 2005, Szklarska Poręba, 16-18 listopada 2005, Wyd. OBR Gospodarki Remontowej Energetyki, Wrocław 2005, s. 199-210.

[12] MIRSKI Z., PIWOWARCZYK T.: Podstawy klejenia, kleje i ich właściwości - Przegląd Spawalnictwa, nr 8/2008, s.12-21.
[13] LOCTITE WORLDWIDE DESIGN HANDBOOK, katalog danych technicznych, HENKEL, 2005.

[14] Henkel, Loctite, Bonderite, Teroson, Tabela doboru produktów, Kleje przemysłowe, uszczelniacze i produkty do przygotowania powierzchni, wydanie 3

[15] http://www.dlautrzymaniaruchu.pl/?id=208\&idk=49\&id_lan$\mathrm{g}=1 \&$ pro=pro

[16] http://edostawca.pl/pl/c/Kleje-epoksydowe-Araldite/79

[17] http://www.kisling.ch/datenblaetter/en/3000/tis_3020_e.pdf

[18] http://www.klejeszu.pl/producenci/LOXEAL/

KLEJE_ANAEROBOWE_DO_ZABEZPIECZANIA/adt-24-18.pdf

[19] http://www.kleje- szu.pl/producenci/LOXEAL/KLEJE_AKRYLOWE/LOXEAL_DANE_TECHNICZNE.pdf

[20] http://www.technicqll.pl/images/TDS/specjalne/TDS_R457_ KLEJ_TERMICZNY.pdf

[21] http://sklep.artom.com.pl/Klej-ceramiczny-RESBOND-919do-1500-st-C-opakowa(3,2260,2523).aspx

[22] http://www.kleje.milar.pl/pdf/Agomet_F_330.pdf

[23] http://riad.usk.pk.edu.pl/ naszapol/np55/str30_32.shtml (Wnuk M. P.).

[24] http://dozowanie.org/e107_plugins/content/content. php?content.44 (Bernaciak M.).

[25] TEROSON - Produkte für Industrie und Handwerk, Henkel Teroson $\mathrm{GmbH}$, Heidelberg. 